\title{
BİR MUHADDîSIN GÖZÜYLE FIKIH VE FAKÎH
}

\section{Yusuf EȘíT*}

\section{Öz}

Hicri beşinci asırda Bağdat'ta yaşamış olan Hatîb el-Bağdâdî İslâmî ilimlerin birçok alanında eserleri olmakla birlikte hadis alanında meşhur olmuştur. Onun yaşadığı asırda İslamî ilimler teşekküllerini tamamlamış, her ilmin kendine has literatür ve dili gelişmiştir. Bununla beraber İslâmî ilimler bir bütünün parçaları olmaları hasebiyle bir birleriyle ilişki ve irtibatları bulunmaktadır. Hatîb el-Bağdâdî bir muhadîs olmasına rağmen sadece rivayetle ilgilenmenin bir bütün olan İslamî ilimlerden istenilen meyvenin eksik alınmasına sebep olduğunu görmüştür. $\mathrm{O}$ hem rivayete hem de dirayete önem vermiş, bu anlamda dönemin sadece rivayetle ilgilenen muhaddislerine dirayetle ilgilenmelerini de tavsiye etmiştir. Hatîb el-Bağdâdî’nin hadisçi özelliğini belirgin bir şekilde yansittığı el-Fakîh ve'l-Mütefakkîh adlı usûl eserinde bu anlayışı görülebilmektedir. $\mathrm{O}$, insanlar arasında Peygamber'in gerçek varisi olarak fakihleri görmektedir. $\mathrm{Bu}$ sonuca fikıhta rivayet ve dirayetin beraber olması özelliğinden ötürü varmaktadır. Rivayet ilimleri olan hadis ve tarihte önemli eserler bırakan Hatîb elBağdâdî’nin dirayete de vurgu yapması önem arz etmektedir. Dolayısıyla bu çalışma onun fikıh ve fakih algısına odaklanmıştır.

Anahtar Kelimeler: F1kıh, Fakîh, Muhaddis, Hatîb el-Bağdâdî, El-Fakîh ve'lMütefakkîh

\section{FIQH AND FAQIH FROM THE PERSPECTIVE OF A TRADITIONIST}

\begin{abstract}
Al-Khatib al-Baghdadi who lived in Baghdad in the hijri fifth century has been famous in the field of hadith despite having lots of works in various fields of Islamic sciences. In the century in which he lived, Islamic sciences completed their formation and each science has developed its own literature and language. However, the Islamic sciences have relations and contacts with one another as they are part of a whole. Although alKhatib al-Baghdadi was a traditionist he saw that the interested by only al-riwayah is incomplete in the giving of fruit which is as a whole islamic sciences. He gave importance to both al-riwayah and al-dirayah, in this sense he advised the traditionists of that time to be interested in al-dirayah too. This understanding of his can be seen in his work named El-Faqîh ve'l-Mütefaqîh trough which he clearly reflects his traditionist aspect. He considers faqihs as true inheritors of the Prophet. He comes to this
\end{abstract}

Makale Gönderim Tarihi:01.11.2018. Kabul Tarihi: 28.12.2018

Doi: $10.26791 /$ sarkiat.477422

* Dr. Öğrt. Üyesi, Batman Üniversitesi İslami İlimler Fakültesi, Temel İslam Bilimleri, yusufesit11@ hotmail.com ORCID ID: 0000-0002-9694-0878 
conclusion since fiqh includes both al-riwayah and al-dirayah. It is important that Alhatîb al-Bagdâdî, who left important works in history and hadith from al-riwayah, emphasized the al-dirayah. Therefore, this study focuses on his perception of fiqh and faqih.

Keywords: Fiqh, Faqih, Traditionist, Al-Khatib al-Baghdadi, El-Faqîh ve'l-Mütefaqîh

\section{GíRiş}

Hicri birinci asrın sonlarından itibaren şekillenmeye başlayan islamî ilimler, ${ }^{1}$ hicri beşinci asırda teşekkülünü tamamlamıştır. Hicri beşinci asır, muhaddîslerin islâmî ilimlerde ağırlığının artık hissedildiği bir dönemdir. Bu asırda Bağdât'ta yaşamış olan Hatîb el-Bağdâdî de İslâmî ilimlerin birçok alanında önemli eserler telif etmiş bir âlimdir. Bununla beraber gerek kendi döneminde gerekse de sonraki dönemlerde şöhret olduğu alan hadîstir. Hadîs usûlü ve hadîs ricâliyle ilgili yazdığı eserler sonraki muhaddîsler için kaynak olmuştur. Onun tarih ve fikıh alanında da yazdığı önemli eserleri bulunmaktadır. el-Fakîh ve'l-Mütefakkîh adlı eseri usûl alanında yazılan nevi şahsına münhasır bir usûl eseridir. Onun bu eserinde en çok göze çarpan husus gerek metot olarak gerekse de içerik olarak muhaddîs kimliğinin ağır basmasıdır. Bir muhaddîs olarak onun fikha ve fukahâya bakış açısı dönemin ehl-i rey ve ehl-i hadîs çatışmasında uzlaşmacı tavrı açısından önem arz etmektedir. Biz de Hatîb elBağdâdî'nin el-Fakîh ve'l-Mütefakkîh adlı eseri çerçevesinde fikıh ve fakîhe olan yaklaşımını tespit etmeye çalıştık.

\section{HATÎB EL-BAĞDÂDî'NIIN HAYATI VE EL-FAKîH VE'L- MÜTEFAKÎH ADLI ESERİ}

\subsection{Hatîb El-Bağdâdî’nin Hayatı}

Tam adı Ebû Bekr Ahmed b. Alî b. Sâbit b. Ahmed b. Mehdî el-Bağdâdî olan Hatîb elBağdâdî 392'de ${ }^{3}$ Mekke-Medine yolu üzerindeki Guzeyye kasabasında dünyaya gelmiştir. ${ }^{4}$ Hatîb lakabını hatiplik yapan babası Ebü'l-Hasen Ali'den ${ }^{5}$ aldığı iddia edildiği gibi kendisinin bu görevi devam ettirmesi sebebiyle aldığı da belirtilmiştir. ${ }^{6}$ Küçük yaşta ilim tahsiline mürebbim dediği Hilâl b. Abdillah et-Tîbî’nin (v. 422/1012) yanında başlamıştır. ${ }^{7} \mathrm{Bu}$ sırada kıraat ilmini öğrenmek için Mansûr el-Habbâl'den (v.

\footnotetext{
${ }^{1}$ Fuat istemi, Hicret Bağlamında Tarih ve Hadis Metodolojileri, Ankara Okulu Yayınları, Ankara 2017, s. 20.

${ }^{2}$ Ebû Abdillâh Şemsüddîn Muhammed b. Ahmed b. Osmân ez-Zehebî et-Türkmânî el-Fârikî ed-Dimaşkî, Tezkîretü'l-Hüffâz, Dârü'l-Kütübi'l-İlmiyye, Beyrut 1998, III, 221; Abdülkerim b. Muhammed b. Mansûr et-Temimî es-Sem'ânî, el-Ensâb, thk. Abdurrahman b. Yahya el-Mua'llimî ve diğerleri, 1. Bask1 Meclisu Dâiretü'l-Me‘arifi'l-Osmaniyye, Haydarâbâd 1962, V, 166; Tâcüddîn Abdülvehhâb b. Takıyüddin esSübkî, Tabkâtü'ş-Şâfi 'iyyeti’l-Kübrâ, thk. Mahmud muhammed et-Tanâhî, Abdü'l-Fettâh, 2. Baskı, y.y. h.1413, IV, 32.

${ }^{3}$ Zehebî, a.g.e., III, 221; es-Sem‘ânî, a.g.e., V, 166; Takıyüddin es-Sübkî, a.g.e., IV, 32.

${ }^{4}$ Ebû Gays Muhammed Hayrüddîn b. Mahmûd b. Muhammed b. Alî b. Fâris ez-Ziriklî ed-Dımaşkî, elA 'lâm, 15. Bask1, Dârü'l-İlim li'l-Melâyîn, Beyrut 2002, I, 172.

${ }^{5}$ Ebû Bekr Ahmed b. Alî b. Sâbit b. Ahmed b. Mehdî el-Bağdâdî, Tarîhu Bağgâd, thk. Beşâr 'Avâd Ma'rûf, Dârü'l-Ğarbi'l-İslâmî, Beyrut 2002, XIII, 279.

${ }^{6}$ Mahmud Tahhân, el-Hâfiz el-Hatîb el-Băgdâdî ve Eseruhu fi 'Ulûmi'l-Hadîs, Dâru'l-Kur'âni'l-Kerîm, Beyrut 1981, s. 30; Mehmet Yaşar Kandemir, "Hatîb el-Bağdâdî", Türkiye Diyanet Vakfi İslâm Ansiklopedisi, İstanbul 1997, XVI, s.452; Necmi Sar1, el-Hatîb el-Bağdâdî ve Hadîs İlmindeki Yeri, 1.Bask1, Ümmülkura Yayınevi, İstanbul 2003, s.12.

${ }^{7}$ Hatîb el-Bağdâdî, a.g.e., XVI, 117.
} 
403/1012) onun vefatı sonrası İbnü's-Saydalânî'den (v. 417/1026) ders almıştır. ${ }^{8}$ O, on bir yaşında iken İbn Rezkûye olarak bilinen Muhammed b. Ahmed el-Bağdâdî'nin (v. 412/1021) Bağdat'ta Camiu'l-Medîne'deki hadîs derslerine iștirak etmiş ${ }^{9}$ ve bu dönemde Irak Şâfîi ekolünün kurucusu olarak gösterilen ${ }^{10}$ Ebû Hâmid elİsferâyînî' $\operatorname{den}^{11}$ (v. 406/1016) ve Ebu't-Tayyib et-Taberî'den ${ }^{12}$ (v.450/1016) ders almıştır.

Hatîb el-Bağdâdî üç yıl aradan sonra (406/1015) tekrar hocası İbn Rezkûye'nin derslerine katılmış ve vefat edinceye kadar (412/1021) devam etmiştir. Bu arada Bağdat'ta Ebu'l-Hasen Ahmed b. Muhammed el-Mehâmilî (v.415/1024) ve Ebû Nasr es-Sabbağ (v.477/1084) gibi meşhur alimlerden hadîs ve fikıh dersleri almıştır. ${ }^{13}$ Yirmi yaşında iken bölgenin ilim merkezlerine ilim yolculuklarına çıkmıştır. ${ }^{14}$

Hicri 423-444 yılları arasında Bağdat'ta kalarak Târîhu Bă̆dâd'1 yazmıştır. Eserini tamamladıktan sonra hac yolculuğuna çıkmış ${ }^{15}$ ve hac yolculuğu dönüşü Bağdat'ta Halife Kâim Biemrillâh'ın ilgisine mazhar olmuştur. Ardından Câmi ‘ü'l-Mansûr'da hadîs okutmaya, Târîhu Băgdâd'1 rivayet ederek gerek tedris gerekse telif çalışmalarına devam etmiştir. ${ }^{16}$ Fâtımîler'in Bağdat şehrini ele geçirmesinden sonra (h. 450) Dımaşk'a kaçmıştır. ${ }^{17}$ Dımaşk'ta Emeviyye Cami'inde ikamet etmiş ve burada Ahmed b. Hanbel'in Fedâillü's-sahâbe'si ile İbn Rezkûye'nin Fedâilü'l-'Abbâs'1n1 okuttuğu için şi'îler tarafından öldürülmek istenince Dımaşk'tan ayrılıp (459) Sûr şehrine gitmiştir. ${ }^{18}$ Hicri 462 yılında Bağdat'a tekrardan dönmüş ve 7 Zülhicce 463 (5 Eylül 1071) yılında Nizâmiye Medresesi yakınındaki evinde vefat etmiştir. ${ }^{19}$

Hatîb el-Bağdâdî muhaddîs kimliğiyle şöhret bulmuştur. Onun hadîsçi yönüyle alakalı ulema şu değerlendirmelerde bulunmaktadır:

Ebû İshâk eş-Şîrâzî: “Ebû Bekr Hatîb, hadîsi bilme ve ezberleme hususunda Dârekûtnî ve onun gibilerine (muhadîslere) benzer". ${ }^{20}$

El-Mu’temen es-Sâcî: “Băgdat Dârekûtnî'den sonra Eb̂̂u Bekr Hatîb’ten daha hafiz birini çıkarmamıştır". ${ }^{21}$

\footnotetext{
${ }^{8}$ Ekrem Ziyâ el-Ömerî, Mevâridu'l-Hatîbi'l-Bağdâdî fi Târihi Bă̆dâd, Dâru Tîbe, Riyad 1985, s. 30; Sar1, a.g.e., s. 14.

${ }^{9}$ Hatîb el-Bağdâdî, a.g.e., I, 211; Ebû'l-Ferec Cemâluddin Abdurrahman b. Ali el-Cevzî, el-Muntazam fi Tarîhi'l-Mülûk ve'l-Ümem, thk. Muhammed Abdülkadir 'Atâ-Mustafâ Abdulkadir 'Atâ, 1. Baskı Dârü'lKütübi'l-İlmiyye, Beyrut 1992, XV, 149; Tahhân, a.g.e., s. 32.

10 Davut EŞIT, Hicrî IV-V. Asırlarda Irak-Horasan'da Şâfi î Fıkıh Usûlünün Gelişimi, Ankara Üniversitesi sosyal bilimler Enstitüsü, Yayınlanmamış Doktora Tezi, Ankara 2017, s. 83-87.

${ }^{11}$ Hatîb el-Bağdâdî, a.g.e., VI, 20.

${ }^{12}$ Hatîb el-Bağdâdî, a.g.e., X, 491.

${ }^{13}$ Sar1, a.g.e., s. 16.

${ }^{14}$ İlim yolculukluları için bk. Kandemir, a.g.e., XVI, s. 453; Sarı, a.g.e., s. 16-18; Abbâs Ali Hamid elUbeydî, el-Menhecü'l-Usûlî li'l-Hatîb el-Bağdâdî fi Kitâbihi el-Fakîh ve'l-Mütefakkih, Merkezü'l-Buhûs ve'd-Dirasât el-İslâmiyye, Irak 2012, s. 33-40.

${ }^{15}$ Kandemir, a.g.e., XVI, s. 453; Sarı, a.g.e., s. 18; el-Ubeydî, a.g.e., s. 33.

16 Zehebî, Târîhu'l-İslâm ve Vefeyâtü'l-Meşâhir ve'l'Alâm, thk. Beşşâr 'Avvâd Ma'rûf, Dârü'l-Ğarbi'lİslâmî, Beyrut 2003, X, 175; Kandemir, a.g.e., XVI, s. 453; Sarı, a.g.e., s. 20; el-Ubeydî, a.g.e., s. 36.

${ }^{17}$ Zehebî, Siyeru A 'lâm 'in-Nübelâ, Dârü'l-Hadîs, Kahire 2006, XIII, 421; Ebü'l-Fidâ' İsmâîl b. Ömer b. Kesîr b. el-Kureşî el-Basrî ed-Dımaşkî eş-Şâfîi, el-Bidâye ve'n-Nihâye, thk. Ali Şirî, 1. Baskı, Dâru İhyâyi’t-Türâsi'l-Arabî, y.y. 1998, XII, 11.

${ }^{18}$ İbn Kesîr, a.g.e., XII, 12; Kandemir, a.g.e., XVI, s. 454; Sar1, a.g.e., s. 24; el-Ubeydî, a.g.e., s. 38.

${ }^{19}$ Kandemir, a.g.e., XVI, s. 454; Sarı, a.g.e., s. 25; el-Ubeydî, a.g.e., s.39-40.

${ }^{20}$ Zehebî, a.g.e., XIII, 421; Takıyüddin Sübkî, a.g.e., IV, 32.
} 
İbn Mâkûla: “Hatîb, Resulüllâh'ın hadîslerini ezberlemek, öğrenmek, sağlam olarak tespit etmek, illet ve isnatlarında uzman olmak, sahihini, garibini, ferdini, münkerini ve atılmış olanlarını bilme hususlarında tanıdığımız seçkinlerin sonuncusudur. Ebu'lHasen ed-Dârekûtnî'den sonra Bağdat'ta Hatîb gibi bir başka âlim yetişmemiştir.,"22

Sem'ânî: "Tartışmasız asrının imamı, vaktinin hafızıydı. Yaklaşık yüz eser telif etmiştir. Muhaddîsler için umde idi.",23

Zehebî bir eserinde onu "Büyük hâfiz, Irâk ve Şâm'ın muhaddîsi"24, diğerinde "zamanının muhaddîsi... hâfizların sonuncusu" 25 şeklinde tanıtmaktadır.

Görüldüğü üzere Hatîb el-Bağdâdî yaşadığı asırda bile hadîsçi kimliği ile şöhret bulmuş ve önemli bir muhadîs olan Dârekûtnî üzerinden hadîsçi yönü ispat edilmeye çalışılmıştır. Dolayısıyla F1kıh ve tarih ilimleriyle olan ilgisi ve bu alanlardaki telifatlarına rağmen şöhret bulduğu alan hadîstir. ${ }^{26}$

\subsection{Hatîb el-Bağdâdî’nin el-Fakîh ve'l-Müitefakkîh Adlı Eseri}

Hatîb el-Bağdâdî'nin hadîsçi kimliğini fikıh usûlü eseri olan el-Fakîh ve'l-Mütefakkîh adlı eserinde de görmekteyiz. Eserinde ele aldığı konular ve konuları ele alış tarzı o döneme kadar şekillenen usûl yazımından farklı olarak kendine özgüdür. Eserinde yer verdiği fıkıh ilminin değeri, bu ilimle iştiğalin hükmü, cedel, fikıh öğrenim ve öğretimdeki adab v.b konular kendi döneminde yazılan usûl eserlerinde bulunmayan yeni konulardır. Hatîb el-Bağdâdî konuları da işlerken konu başlığı ile ilgili hadîs, sahabe ve ulemadan rivayetleri senetleriyle birlikte serdetmektedir. Bu, hadîs ehlinin hadîs eserlerinde takip ettiği bir metottur. Hatîb el-Bağdâdî'nin böylece hem metodik olarak hem de içerik olarak yazıla gelen usulden farklı muhaddîs kimliğinin ağır bastığı bir usûl yazdığı söylenebilir. Bu şekildeki bir usûl yazımını mütekelim-fukahâ grublarından biri içerisinde değerlendirmek güçtür. El-Ubeydî, gerek Hatîb elBağdâdî'nin Şâfi'î olup mezheb imamının görüşlerini eserinde desteklemesi ve gerekse eserinde kimi kelâmî konulara yer vermesi sebebiyle el-Fakîh ve'l-Mütefakkîh'i mütekellim usûlü kapsamında değerlendirmektedir. ${ }^{27}$ Ancak Şâfi'înin risâlesinin mütekelim usûlü kapsamında oluşu bile tartışmalı iken salt Şâfi'î olması ve Şâfi'î'nin görüşlerini desteklemesi onun eserini mütekellim usûlü kapsamında değerlendirme için bir ölçüt olmaz. Öte yandan kendisinin kelâmî konulara çok az ve usûl tartışmalarından bağımsız olarak yer vermesi nedeniyle Tarîkatü'ş-Şâfi iyye olarak da bilinen mütekellim metodu kapsamında değerlendiremeyiz. Mütekellim usûlcülerinin en önemli özelliği olarak belki kelamcı yanlarını usûle yansıtmaları ${ }^{28}$ ve kimi kelâmî tartışmalara kendi görüş ve bakış açılarına göre katılıp usûl eserinde usûl konuları içerisinde yer vermeleridir. Bu hususun Hatîb el-Bağdâdî’de olduğunu söylemek güçtür. Diğer taraftan furû' örneklerine yer vermediği için Tarikâtü'l-Hanefiyye olarak da nitelendirilen fukahâ usulü kapsamında olduğu da söylenemez. Bu esere, ehl-i hadîsin

\footnotetext{
${ }^{21}$ Zehebî, a.g.e., XIII, 421; Takıyüddin es-Sübkî, a.g.e., IV, 31.

${ }^{22}$ Zehebî, a.g.e., XIII, 421; Takıyüddin es-Sübkî, a.g.e., IV, 31.

${ }^{23}$ Sem'ânî, a.g.e., V, 166.

${ }^{24}$ Zehebî, a.g.e., III, 221.

${ }^{25}$ Zehebî, a.g.e., XIII, 419.

${ }^{26}$ Kandemir fikıh sahasında çalışmalar yapmasına ve ileri gelen Şâfiî fakihlerinden olmasına rağmen muhaddîsliğinin fakihliğinden üstün olduğunu söylemektedir. a.g.e., XVI, s. 454.

27 el-Ubeydî, a.g.e., s. 84-85.

${ }^{28}$ Kelamcıların usûl alanında eser yazma sebepleri için bk. Eşit, a.g.e., s. 99-106.
} 
bir usûl yazımı denemesi olarak bakılması yerinde bir değerlendirme olacağ kanisindayız.

\section{FIKIH VE FIKIH USULÜNÜN TANIMI}

Hatîb el-Bağdâdî, fikhın sözlük anlamını bilmek olarak tanımlamaktadır. ${ }^{29}$ Bu husus fıkhın tanımını zikretmek için aktardığ 1 rivayetlerde ${ }^{30}$ açıkça görülmektedir. Bu rivayetlerdeki ortak husus, fikhın anlamının "anlamak" ve "bilmek" şeklinde tarif edilmesidir. Her bilgi anlamayı gerektirdiği, her anlama da bilgiyi gerektirdiği için bilgi ve anlama birbirlerinin yerine kullanılmaktadır.

O, fikhı terim olarak şöyle tanımlamaktadır: "Ebû İshâk İbrahim b. Ali el-Fakîf elFîrûzâbâdî (eş-Şirâzîl'den duydum ki fikıh: ictihâd yoluyla ulaşılan şer'î amelî hükümleri bilmektir." 31

$\mathrm{Bu}$ tanımı eserinde zikretmesi aynen katıldığ 1 anlamındadır. $\mathrm{Bu}$ tanım bilgi olarak tanımladığı fikhın sözlük anlamıyla da uyumludur. Ancak her türlü bilgiyi fikhın kapsamından çıkarmaktadır. $\mathrm{Bu}$ tanıma göre ulaşılan bilginin fikıh kapsamında olabilmesi için iki şart gerekmektedir. Birincisi bilginin şer'in amel alanına ilişkin olması; İkincisi ise ictihâdla ulaşılmış olması gerektiğidir. İctihâtla ulaşılmayan bilgiler fikıh olarak isimlendirilmemektedir. Bu tanım hem Ebû İshâk eş-Şirâzî’nin (v. 476/1083) hem de Hatîb el-Bağdâdî'nin çağdaşı olan Cüveynî'nin (v. 478/1085) ${ }^{32}$ de fikıh tanımıdır. Onlardan önce fikhı ictihâd ve istinbât ile ulaşılan bilgiler olarak tanımlayan İbn Fûrek’tir (v. 406/1015). ${ }^{33}$ Ancak İbn Fûrek tanımında “amel” kaydını

${ }^{29}$ Tanım ile alakalı rivayetler için bk. Ebû Bekr Ahmed b. Alî b. Sâbit el-Bağdâdî, el-Fakîh ve'lMütefakkih, thk. Ebû Abdirrahman Adil b. Yusuf, 1. Bask1, Dârü İbni'l-Cevzî, Suud 1996, I, 189-190.

${ }^{30}$ Ebû'l-Feth Ahmed b. Ali b. Muhammed en-Nühas-Hüseyin b. Ali b. Ubeydullah el-Üsâmî-Musa b. ElKâsım b. Musa b. El-Eşyebel-Kâdî-Sa'leb: Ahmed b. Yahya en-Nahvî dedi ki: "Adamın fikhı kemale erdiğinde 'fekuhe', fikıhtan az bir şey ögrendiğinde ise 'fekihe' söylenir”. Hatîb el-Bağdâdî, a.g.e., I, 189. Ebû'l-Hasan: Muhammed b. Abdü'lvâhid b. Muhammed b. Ca'fer- Ebû Ömer: Muhammed b. El-Abbâs el-Hazzâz- Ubeydullah b. Abdurrahman es-Sükrî- Ebû Muhammed: Abdullah b. Müslim b. Kuteybe dedi ki: "Fıkı sözlükte fehm/anlama demektir. Falan benim sözümü anlamadı (يقة) diye ifade edilir. Allah teala da şöyle buyurmuştur: 'Her şey O'nu hamd ile tespih eder. Ancak, siz onların tespihlerini fiketmezsiniz.' (el-İsrâ 44) yani anlamazsınız. Sonra ilme fikıh denmiştir. Çünkü ilim anlamakla olur. Alime de fakih denmiştir. Çünkü alim de ancak fehmiyle ögretir. (bu şekilde kullanım) Araplar'da bir şeyin sebebinin ismini almasıdır."

Hasan b. Ebî Bekir, Muhammed b. El-Hasan İbn Ziyâd el-Mukrî en-Nekkâş, Muhammed b. Alî es-SâiğMuhammed b. Muaviye-İbn Lehî'e-'Atâ İbn Dînâr "Sa 'îd b. Cübeyr'e dinde tefaküh sorulmuş ve demiş ki: Allah'ın emrini, nehyini bilmek, Nebi'nin sünnetini bilmeye dair emrini bilmek,ve bildiğini muhafaza etmek. Ișste dinde fikıh budur"

Ali b. Ebî Ali el-Basrî-İsamil b. Sa‘id b. İsmail b. Süveyd el-mu'addel-Ebû Bekir: Muhammed b. elKasım el-Enbârî dedi ki: "Adam fakihtir sözlerinin anlamı alim olmasıdır. Her bir şeyi bilen onda fakihtir........arapların fakihi demek arapların alimi demektir. Bundan ötürü Allah'ın 'dinde fakih olsunlar diye' (et-Tevbe: 122) sözünün anlamı alim olmak demektir."”

${ }^{31}$ Hatîb el-Bağdâdî, Şirâzî’nin tanımını kendisinden işittiğini ifade ederek aktarmaktadır. a.g.e., I, 190. Şirâzî'nin tanımı için bk. el-Lüma ' fî Usûli'l-Fılkh, thk. Abdülkâdir el-Hatîb el-Hasanî, 1. Bask1, Dârü'lHadîs el-Kâtaniye, Beyrut 2013, 82.

32 İmâmü'l-Haremeyn Ebü'l-Meâlî Rüknüddîn Abdülmelik b. Abdillâh b. Yûsuf el-Cüveynî et-Tâî enNîsâbûrî, el-Varakât, İbn Ferkâh'ın Şerhü'l-Varakâtıyla birlikte, Dârü'l-Kütübi'l-i̇lmiyye, thk. Muhammed Hasan Muhammed Hasan İsmail, Lübnan 2010, s.12. Ancak O el-Burhân adlı eserinde fikhı "şer'î hükümleri bilmek" olarak tanımlayarak fikhı sözlük anlamına uygun olarak bilgi şeklinde tanımlarken söz konusu bilginin ilişkin olduğu alan (ameli-itikadi-ahlaki) ve bilginin değeri (kat' ${ }^{\prime} \hat{1}$-zannî) daha geniş tutmuştur. el-Burhân, thk. Abdülazîm ed-Dîb, 1. Baskı, Katar h.1399, I, 85.

33 İbn Fûrek'in fikıh tanımı şöyledir: "Fıkhın tanımı: O, ictihâd ve istinbât ile ulaşılan şer 'î hükümleri idrak etmektir." Ebû Bekr Muhammed b. el-Hasen b. Fûrek el-İsfahânî en-Nîsâbûrî, Kitâbü 'l-Hudûd fi'lUsûl, 1. Baskı, Dârü'l-Ğarbi’l-İslâmî, Beyrut 1999, 139. 
koymamakta ve fikhı şer‘î hükümlerin tümünü kapsayacak şekilde tanımlamaktadır. Bununla beraber bu tanımlarda ortak olan nokta, zorunlu olarak bilinen ile ictihâd yoluyla ulaşılan bilgi ayırımının yapılması ve fikhı, ictihâd ile ulaşılan bilgi kapsamında değerlendirmeleridir. Bu aynı zamanda fakihin görev alanının ictihâdî konular olduğunu göstermektedir.

\section{FIKIH VE FAKÎHİN DEĞERİ}

Hatîb el-Bağdâdî, fıkıh ile iştigali kimi ibadetlerden üstün görmektedir. $O$, fıkıh ögrenimi ve ögrretiminin cihattan, ${ }^{34}$ nafile namazdan, ${ }^{35}$ malın tasadukundan daha değerli olduğuna $^{36}$, Kur'ân öğretimi ile fikıh öğretiminin salât olduğuna ${ }^{37}$ dair rivayetleri aktarır.

Fıkıhla iştigal kimi ibadetlerden üstün olunca fukahâ da abidler'den daha hayırlı olmaktadır. Hatîb el-Bağdâdî bunu ifade eden rivayetler aktarır. ${ }^{38} \mathrm{O}$, ibadet-fikıh ilişkisi hakkında şu değerlendirmeyi yapar: "İbadet ancak tefekkuhten sonra sahih olur." 39 Hatîb el-Bağdâdî, bir sonuç olan bu değerlendirmesini zikrettiği rivayetlere dayandırmaktadır. ${ }^{40}$ Böylelikle ibadetin kendisinin sıhhatinin bile fikhı bilmeyi gerektirdiğini bu açıdan fikhın sıhhat ölçütü olduğunu ifade etmeye çalışmaktadır.

Hatîb el-Bağdâdî, fıkıh-ibadet ilişkisi anlayışını fikıh meclislerinin faziletine dair başl1kta da sürdürür. O, gerek ayette geçen ve gerekse hadîste geçen Allah'1 zikredip dua edenlerin kurduğu meclisin fikıh meclisi olduğuna dair görüşleri aktarır. Örneğin

\footnotetext{
${ }^{34}$ Ebû Sa‘îd b. Ebî Hesnuyeh el-İsfehânî-Ebû Ca‘fer: Ahmed b. Ca‘fer b. Ma‘bed es-Simsâr- Yahyâ b. Mutarrif-Suleymân b. Dâvud-Ebû Abdullah el-Ezdî-Muhamed İbn Mutarrif-İsmâil-Sa'îd el-Mukrî-Ebû Hureyre şöyle demiştir: "Emir ve nehiy ilminden bir bab öğrenmem Allah yolunda yetmiş gazveye isstirakten daha sevimlidir". Hatîb el-Bağdâdî, a.g.e., I, 102.

${ }^{35}$ Ebû Nasr: Abdü'l-Vehhâb b. Abdullah b. Ömer-Ebû Süleymân Myhammed b. Abdullah er-Rebi‘îAbdullah b. Muhammed el-Bağâvî-İbrahim b. Hânî Ahmed b. Hanbel'e şöyle sordu: “Akşam oturup istinsah yapmam mı nafile namaz kılmam mı sana daha sevimlidir." Ahmed b. Hanbel şöyle cevap verdi: "istinsah edip dini öğrenmen bana daha sevimlidir". Hatîb el-Bağdâdî, a.g.e., I, 104.

${ }^{36}$ Ebû Sa'îd-Ahmed b. Ca'fer b. Ma'bed-Ebû Heysem: Yahyâ b. Mutarrıf-Süleymân b. Dâvud, Fudayl b. İyaz-Hişâm-Hasan dediki: "İlimden bir bab ögrrenip bir Müslümana ögretmem Allah yolunda infak edeceğim tüm dünya malından daha sevimlidir". Hatîb el-Bağdâdî, a.g.e., I, 102.

${ }^{37}$ Ebû Bekir el-Burkânî-Muhammed b. Muhammed el-Haccâcî-Muhamed b. İshâk b. Hüzeyme-Hüseyin İbn Seleme b. Ebî Kebşe-Muhammed b. Bekr-Hümeyd el-Kindî-Yahya b. Ebî Kesîr dedi ki: "Fıkhı ögretmek salattır. Kur'ân ögretmek de salattır’. Hatîb el-Bağdâdî, a.g.e., I, 103.

${ }^{38}$ Ali b. Ahmed b. Ömer el-Mukrî-Muhammed b. Hüseyn el-Âcûrî-Ebû'l-'Abbâs:Ahmed b. Mûsâ b. Zencûyeh el-Kattân-Hişâm b. 'Ammâr ed-Dımaşkî-Hafs b. Ömer-Osman b. 'Atâ-Ebû'l-'Atâ-Ebû DerdâResulüllâh dedi ki: “Âlimin âbide üstünlüğ̈̈ dolunaylı gecede kamerin diğer ylldızlara üstünlüğ̈̈ gibidir. Âlimler peygamberlerin vârisleridir. Peygamberler, ne dinar ne dirhem miras bırakırlar, ama ilim miras bırakırlar. Kim de ilim elde ederse, bol bir nasib elde etmiştir". Hatîb el-Bağdâdî, a.g.e., I, 105.

Hasan b. Ebî Bekr- Ahmed b. İshâk b. Nîhâb-Hasan b. Ali es-Sirrî-Ahmed b. Hüseyn el-Lehebî-Ebû Damra: Enes b. 'İyâz-Muğîre-İbn Ebî Revvâd:"Bir adam Rasullüllah'a (s.a.v) biri Allah'a ibadet eden diğeri farzların dlşında başka ibadet etmeyip insanlara ilim ögreten iki kişiden bahsetti. Rasullüllah (s.a.v) de: 'Âlimin âbide üstünlüğ̈̈ benim sizden en basitinize olan üstünlüğüm gibidir' buyurdu'. Hatîb el-Bağdâdî, a.g.e., I, 106-107.

Ebû Sa‘îd: Muhammed b. Musâ es-Sayrafî-Ebü'l-Abbâs:Muhammed b. Ya‘kub el-Essam-Hârûn b. Süleymân el-İsfahânî-Abdurrahman b. Mehdî-Muhammed b. Nadr el-Hârisî-Rebi` İbn. Hüseym şöyle buyurdu: "Fıkhı öğren sonra inzivaya çekil". Hatîb el-Bağdâdî, a.g.e., I, 107.

Hasan b. Ali el-Cevherî-Ebû Ubeydüllâh: Muhammed b. 'İmrân b. Musâ el-Mirzabânî-ahmed b. Muhammed b. İsâ el-Mekkî-Muhammed b. Kâsım b. Hellâd-Mutarrif b. Abdullah b. eş-Şihhir şöyle rivayet edilir: "Illim amelden daha üstündür. Geceyi ibadetle geçiren rahibin sabaha şirke düştüğ̈̈nü görmez misin?" Hatîb el-Bağdâdî, a.g.e., I, 109-110.

39 "و لا تصح العبادة الا بعد التفقه", Hatîb el-Bağdâdî, a.g.e., I, 107.

${ }^{40}$ Rivayetler için bk. Hatîb el-Bağdâdî, a.g.e., I, 107-110.
} 
"Sabah akşam Rablerine, O'nun rizasını dileyerek dua edenlerle birlikte ol" (el-kehf: 28) ayetinde geçen dua edenlerin oluşturduğu meclisin fikı meclisi olduğuna dair görüşü aktarır. ${ }^{41}$ Rivayetleri tenkide ve yoruma tabi tutmadan eserinde yer vermesi aynen katıldığı anlamındadır. Dolayısıyla ayette teşvik edilen meclisin fikıh meclisi olduğuna kendisinin de katıldığını söyleyebiliriz.

Hatîb el-Bağdâdî Resulullâh'ın “Güneş doğuncaya kadar Allah'ı zikreden bir kavimle oturmam, güneşin üzerine doğduğu şeylerden bana daha sevimlidir. İkindiden güneş batıncaya kadar (Allah'ı zikredenlerle oturmam) şunlardan bunlardan bana daha sevimlidir" dediği şeklindeki hadîsi aktardıktan sonra Yezîd Rakkâşî’nin, Enes b. Mâlik'in bu hadîsi rivayet ederken kendisine dönüp söylediği şu söze yer verir: "Vallahi $b u$ (hadîste övülen davranış) senin ve arkadaşlarının yaptı̆̆ değildir. Ancak onlar (hadîste geçenler) Kur'ân'l ve fikhı ögretenlerdir." "42

Hatîb el-Bağdâdî fikıh meclisinin zikir meclisinden faziletli olduğuna dair farklı varyantları bulunan şu rivayete de yer verir: "Nebi (s.a.v) meclise girdiğinde biri fikıh ögretenlerin diğeri Allah'ı zikir edip onu arzulayanların oluşturduğu iki grup görür ve şöyle der: İki grup ta hayır üzeredir. Biri diğerinden daha hayırlıdır. Biri Allah'ı dua edip onu arzulamaktadır. Allah isterse onlara verir isterse vermez. Ancak şunlar ögreniyor ve cahillere ögretiyorlar. Bende ancak muallim olarak gönderildim" diyerek yanlarına oturur. ${ }^{43}$ Bunun yanında fikıh meclislerini cennet bahçesi olarak niteleyen rivayetler de aktarır. ${ }^{44}$

Son rivayet ile yukarıdaki rivayetleri bir bütün olarak ele aldığımızda Hatîb elBağdâdî'nin fikıh ile iştigali Allâh'ı zikretmekten daha hayırlı gördüğü; ayetlerde övülen ve teşvik edilen zikir ve dua meclislerinin fikıh meclisi olarak yorumladığ 1 anlaşılmaktadır.

Hatîb el-Bağdâdî fikıh ilmini öğrenmenin hükmünü ilim öğrenmenin hükmü üzerinden ele alarak bir sonuca varmaya çalışır. O, Konuyla alakalı olarak Rasûlullâh'ın (s.a.v) "Ilim talep etmek her mümin üzerine farzdır" "45 hadîsini ve bu hadîse dair görüşleri aktarır. ${ }^{46}$ Hatîb el-Bağdâdî bu hadîste kast edilen ve farz olduğu belirtilen ilmin namaz, oruç, haram, hadler ve diğer hükümler olduğunu belirtir. $\mathrm{O}$, bu hadîsle kast edilen farz ilimle alakalı tevhit ilmi olduğuna; bir beldede kimse yerine getirmediğinde herkese farz olduğuna dair görüşleri aktarır. İlmin ilk etapta kifâî farz olduğu akabinde ayniye dönüştüğü şeklindeki bu ikinci görüş, İbn Uyeyne’ye dayandırılmaktadır. ${ }^{47} \mathrm{Bu}$ görüşe karşı çıkan Hatîb el-Bağdâdî, Allah'ın varlığı birliği, sıfatları gibi kelamî konuların niyabet kabul etmediğini; dolayısıyla bu bilgileri bilmenin herkese farz olduğunu

\footnotetext{
${ }^{41}$ Hatîb el-Bağdâdî, a.g.e., I, 92. Yine Dahhâk’ın “Öğretmekte ve derinlemesine incelemekte olduğunuz kitap" (Âli ‘İmrân: 79) ayetinde kastedilen fikıh öğretiminin yapıldığı meclis olduğuna dair görüşünü aktarır. Hatîb el-Bağdâdî, a.g.e., I, 96.

${ }^{42}$ Hatîb el-Bağdâdî, a.g.e., I, 88-90.

${ }^{43}$ Eserin muhakkiki bu rivayetlerin isnatlarını zayıf olarak nitelemektedir. Bk. Hatîb el-Bağdâdî, a.g.e., I, 88

${ }^{44}$ Rivayetler için bk. Hatîb el-Bağdâdî, a.g.e., I, 93-96.

45 İbn Mace, Mukaddime, 17. Bağdâdî, bu hadîsin "ilim" yerine "fikh" kelimesinin geçtiği farklı varyantlarını da aktarır: "Fıkıh talep etmek her Müslüman üzerine farzdır", "dinde tefakküh her Müslümanın hakkıdır", “fıkıh talep etmek her Müslümana farzdır”. Bu rivayetler, Hatîb el-Bağdâdî’nin ilmi niçin fikıh olarak anladığı hakkında bilgi vermektedir. Ancak eserin muhakkiki Ebû Abdirrahman ilk rivayetin isnadının zayıf, ikincisinin uydurma üçüncüsünün ise isnadının zayıf ancak liğayrihi sahih olduğunu söylemektedir. Hatîb el-Bağdâdî, a.g.e., I, 169

${ }^{46}$ Hatîb el-Bağdâdî, a.g.e., I, 168-173.

${ }^{47}$ Hatîb el-Bağdâdî, a.g.e., I, 170.
} 
belirtir. Ancak o, İbn Uyeyne'nin kifâi olduğunu söylediği ilmin, füru'a ilişkin fikhî hükümler olması gerektiğini söyler. ${ }^{48}$

Hatîb el-Bağdâdî daha sonra farz olan ilmin kişinin kendisine gereken zamanda gerektiği kadarını bilmesi ile kayıtlandıran görüşü aktarır. $\mathrm{Bu}$ görüşe göre kişinin halinin gerektirdiği kadarını bilmesi farzdır. $\mathrm{O}$, bu görüşü Abdullâh İbn Mübârek'ten aktarılan rivayetle izah etmeye çalışır. Abdullâh İbn Mübârek'e göre malı olmayanın zekâta ilişkin hükümleri bilmesi gerekmez. Ancak malı olduğunda malından ne kadar zekât çıkarması gerektiğini bilmelidir. ${ }^{49}$ Bu şekilde hadîsin anlaşılması ile alakalı olarak üç farklı görüş aktarmaktadır.

Hatîb el-Bağdâdî herkesin Allah'ın farz kıldıklarından ictihâdlarının el verdiği ölçüde kendilerine lazım gelenleri bilmelerinin vacip olduğunu belirtir. Kişinin bilmesi gerektiği konuları da şu şekilde sıralar: Taharet, namaz, oruç, yiyecek-içecek-giysi-malkan ve evlenilecek karşı cinslerden kendisine helal olan ve haram olanlar. Hatîb elBağdâdi kişinin bütün bu hususlarda cehalet gösteremeyeceğini belirtir. $\mathrm{O}$, Müslüman çocuklarının buluğa ermeden, sonradan Müslüman olan ergenlerin ise Müslüman olur olmaz bu hükümleri öğrenmelerini gerekli görür. Hatîb el-Bağdâdî, bu ilimleri eşlerine öğretmeleri için devlet başkanının kocalara baskı yapabileceğini ve bu ilimlerin insanlar tarafından bilinmesini sağlamanın devlet başkanına farz olduğunu belirtir. ${ }^{50}$

Hatîb el-Bağdâdî'nin yukarıda bilinmesi gerekenler kapsamında değerlendirdiği konular fikıh eserlerinde yer alan konulardır. Ancak herkesin bilmesi gerektiği şeklinde sıraladığ bu konular, bireylerin hayatlarında çokça yer alan helal ve harama ilişkin hükümlerdir. $\mathrm{Bu}$ hükümler ictihâd ile ulaşılan bilgiler kapsamında olmadığından kendisinin yaptığı fikıh tanımı kapsamına da girmemektedir. Kendisinin yaptığ 1 tanım, müctehidlerin ilgi alanındaki bilgileri kapsarken bu bilgiler ictihâd gerektirmeyen bilinmesi gerekli bilgileri kapsamaktadır. ${ }^{51}$

Yukarıda İbn Uyeyne'nin görüşüne getirdiği yorum ile bu yaklaşımı arasında tutarlılık olduğu görülmektedir. Şöyle ki yaptığı yorumda fikhı, kifâî farz olarak değerlendirmektedir. İctihâd alanı olarak gösterdiği fikıh uğraşısını kifâî farz olarak görürken, bilinmesi ictihâda dayalı olmayan bilgileri ise her kesin bilmesi gereken fikıh tanımı dışında değerlendirir. Böylece Hatîb el-Bağdâdî "İlim talep etmek her mümin üzerine farzdır" hadîsine kendisince bir açıklık kazandırmış ve kelama ilişkin konular ile yukarıda yer verdiği fikha ilişkin konuları herkesin öğrenmesi gereken farzlar olarak görmekte ve söz konusu hadîsi bu çerçevede ele almaktadır. Esasında bu hadîs aynı zamanda bilinmesi gerekli olan konuların neliği sorusuna cevap sadedinde ilmihallerin doğmasına sebep olmuştur. ${ }^{52}$ Nitekim Hatîb el-Bağdâdî bu hadîse dair şu görüşü

\footnotetext{
${ }^{48}$ Hatîb el-Bağdâdî, a.g.e., I, 171.

${ }^{49}$ Hatîb el-Bağdâdî, a.g.e., I, 171-172.

${ }^{50}$ Hatîb el-Bağdâdî, a.g.e., I, 173-174.

${ }^{51}$ F1kıh ilminde bilgi tartışmaları için bk.: Davut Eşit; Muhammet Enes Kala, "Onüçüncü Yüzyıl İslâm Hukuk Felsefesinde Bilginin Mahiyeti -Âmidî ve Zerkeşî Örneği-" Uluslararası 13. Yüzyllda Felsefe Sempozyumu Bildirileri, Yıldırım Beyazıt Üniversitesi, Ankara 2014, 188-209; Davut Eşit, "Klasik Dönem Fıkıh Usûlü Eserlerinde Bilginin Kısımları”, e-Şarkiyat İlmi Araştırmaları Dergisi, cilt: 10, sayı: 1, 2018, ss. 43-155.

$52 \mathrm{Bu}$ hadîsin ilmihal olarak yorumlandığına dair değerlendirme için bk. Hatice K. Arpaguş, "Bir Telif Türü Olarak İlmihal Tarihi Geçmişi ve Fonksiyonu”, Marmara Üniversitesi Illahiyat Fakültesi Dergisi, S. 22 , s. 28
} 
sahibine nispet etmeden (قيل) aktarır: "İlm-i hâli için cahil kalamayacağı şeyleri ögrenmesi her bir kişiye farzdır". 53

Erken dönemden itibaren hem ilm-i hâl kavramının kullanılması ve bu kapsamda yer alması gereken konuların neliğinin tartışılması ve hatta bunun eğitimi işinde devletin sorumluluk ve yetkisinden bahsedilmesi önemlidir. Hatîb el-Bağdâdî'nin yukarıdaki aktarımları onun bir ilm-i hâl yazması halinde eserinde hangi konulara yer vereceğinin ip uçlarını da bizlere sunmaktadır.

\section{DİNî ANLAMA MERTEBELERİNDE FUKAHÂNIN YERİ}

Hatîb el-Bağdâdî bu başlık altında Hz. Peygamber'in şu hadîsini aktararak fukahânın dini anlamadaki yerini izah etmeye çalışır: ${ }^{54}$

Hz. Peygamber şöyle buyurdular: "Allah'ın benimle gönderdiği ilim ve hidayetin misali, bir araziye düşen yağmur gibidir. Bazı araziler var, tabiatı güzel olup, suyu kabul eder, bol bitki ve ot yetiştirir. Bir kısım arazi de var ki münbit olmaylp ot bitirmez ancak suyu tutar. Onun tuttuğu su ile Cenab-ı Hakk insanları yararlandırır. Bu sudan kendileri içerler, hayvanlarını sularlar ve ziraat yaparlar. Diğer bir araziye daha isabet eder ki, bu ne su tutar ne ot bitirir. Bu temsilin biri Allah'ın dininde ilim sahibi kllınana delalet eder, böylesini Allah benimle göndermiş olduğu hidayetten yararlandırır; yani hem ögrenir, hem ögretir. Temsilden biri de, buna iltifat etmeyen Allah'in benimle gönderdiği hidayeti hiç kabul etmeyen kimseye delalet eder."

Hatîb el-Bağdâdî Rasûlullâh'ın bu hadîste fakîh ve muteffakih mertebelerini topladığını belirtir. ${ }^{56}$ Ona göre Peygamber bu hadîsinde üç grup insandan bahsetmektedir. Hatîb elBağdâdî, Peygamber'in münbit araziler olarak tasvir ettiği grubu fakîh olarak niteler. Bu araziler suyu kabul etmekte ve bu arazilerde bol bitki yetişmektedir. Hatîb el-Bağdadi bu arazi ile kast edilenin rivayet edilenleri zabt edip manalarını kavrayan ve ihtilaflı olanları Kitâb ve Sünnet'e arz edenler olduğunu belirtmektedir. Ona göre kurak ancak suyu tutup insanların bu sudan yararlanmasını sağlayan arazi ile rivayetleri sadece hifz edip aktaranlar kast edilmektedir. Hatîb el-Bağdâdî bu grubun rivayetleri hıfz ettiğini, rivayetlerde anlam itibariyle tasarruflarda bulunmadan ve rivayeti değiștirmeksizin diğer insanlara ulaştıran kimseler olduğunu belirtir. Bu grup tebliğ işlevi görerek anlama ihtimali olan başka insanlara rivayetleri olduğu gibi aktarmaktadır. Hatîb elBağdâdî, "Bir kısım teblĭg edilen, dinleyenden daha anlayışlıdır. Bir kısım fikıh taşıyıcısı ise fakih değildir" hadîsini de bu grup için delil olarak zikreder. Ne suyu tutan ne de suyu taşıyan arazi temsili ile ise cahil kimseleri kastetmektedir. "Kendisine âyetlerimizi verdiğimiz hâlde, onlardan sıyrılıp da şeytanın kendisini peşine taktı̆̆ yüzden de azginlardan olan kimsenin haberini onlara anlat... Onun durumu şöyle bir köpeğin durumu gibidir ki;..." (el-“Araf: 175-176) ayetlerinden yola çıkarak ilimi hor görmek suretiyle ondan yüz çevirenlerin Kur'ânda köpeklere benzetildiğini belirtir. ${ }^{57}$

Hatîb el-Bağdâdî, bu hadîs ve akabinde getirdiği yorumlarla insanları üç grupta değerlendirmektedir. Birincisi ve mertebece en üstünü kendisinin de belirttiği üzere fakihlerdir. Onlar hem dinin aktarılmasında hem de anlaşılmasında önemli rol oynamaktadırlar. Hadîste geçtiği üzere Peygamber'in hidayet görevi dini başkalarına

\footnotetext{
أنّ على كل أحد فرضاً أنْ يتعلّم ما لا بسعه جهله من علم حاله، Hatîb el-Bağdâdî, a.g.e., I, 171 .

${ }^{54}$ Hatîb el-Bağdâdî, a.g.e., I, 179.

55 Buhâri, İlim, 20; Muslim, Fedâil 15 (2282).

${ }^{56}$ Hatîb el-Bağdâdî, a.g.e., I, 180.

${ }^{57}$ Hatîb el-Bağdâdî, a.g.e., I, 180-181.
} 
öğrettiklerinden ötürü bu sınıfa verilmiştir. $\mathrm{Bu}$ grup fikıh ilmi ile iştigal eden fakihlerdir. İkinci grup ise rivayet ile ilgilenen alimlerdir. Kendisi bu grup için "taife" nitelemesini kullanır ve herhangi bir ilim erbabına nispet etmez. Ancak bu kesimin hadîs rivayeti ile iştigal eden muhaddîsler olduğu açıktır.

Muhaddîs olarak bilinen Hatîb el-Bağdâdî’nin fikhı ve onunla iştigal eden fakihleri mertebece en üst sırada kabul etmesi muhaddîs kimliğiyle tezat teşkil etmemektedir. Neticede bu şekilde bir sonuca varırken hareket noktasını hadîs teşkil etmektedir. Hatîb el-Bağdâdî ehli hadîse nasihatlerde bulunduğu risâlesinde hadîsçinin sadece rivayetle yetinmemesini, anlamını bilerek rivayette bulunmanın daha uygun olduğuna dair rivayetleri aktarır. Söz konusu bu rivayetlerden ikisi şunlardır: "(Hadîsi) bilenler olunuz, nakledenler değil. Yorumunu bildiğiniz bir hadîs, rivayet ettiğiniz bin hadîsten daha faydalıdır."58 "Bil ki çok hadîs yazma ve rivayetle kişi fakih olamaz. Kişi ancak hadîsin manalarını anlamaya çalışarak ve üzerinde derin ve etraflıca düşünerek fakih olur." ${ }^{, 59} \mathrm{Bu}$ yaklaşım onun muhaddîs kimliğinin fikıhla yoğrulması ile ortaya çıkan ve salt rivayete dayanan bir ilmî anlayışı doğru bulmayan bir yaklaşımdır. El-Fakîh ve'lMütefakkih adlı eserinde her konu başlığı altında ilintili rivayetleri serdederken aynı zamanda ihtiyaç duyduğu zaman kendisinin açıklamalar yapması bu anlayışının bir sonucudur. Tefakkuha (fikıh öğrenme/dinde bilgi sahibi olma) özel ilgisi olduğu ve rivayet işi ile uğraşanları bu alana sevk etmeye çalıştı̆̆ı açıkça görülmektedir. Farklı eserlerinde ortaya koyduğu tavır aynı olup tutarlılık göstermektedir. Hem rivayet hem de dirayeti barındıran fikhı el-Fakîh ve'l-Mütefakkih adlı eserinde övünce muhaddîslere tavsiye diye yazdiğ 1 eserinde muhaddîsleri rivayet ettiklerini anlamaya yönlendirmesi bu tutarlı davranışın bir sonucudur.

Hatîb el-Bağdâdî'nin muhaddîsleri rivayetleri anlamaya yönlendirmesi veya fikıhla iştigal etmeye yönlendirmesinin sebebi dönemin ehl-i rey ve ehl-i hadîs muhalefetidir. Nitekim onun bu konudaki şu ifadesi bunu açıkça göstermektedir: "Muhalifler, muhaddîsunu usul-i fikhl, sünenlerin ihtiva ettiği delilleri ve asıl konularını bilmediklerini dile getirmede acele ediyorlar. Muhaddîs, bunları derinlemesine bildiği zaman, tenkit edenlerden korunacak, göz ve gönüllerde yer tutacak, onlarl ta'n etmek isteyenler de kendisinden çekineceklerdir. ${ }^{, 60} \mathrm{Bu}$ ifadeler aynı zamanda muhaddîs olarak Hatîb el-Bağdâdî'nin de muhaddîslere yönelik eleştirisini içermektedir. Kendisi de muhaddîslerin sadece rivayetle ilgilenmelerini doğru bulmamakta ve onlara fikıhla ilgilenmeyi nasihat etmektedir. ${ }^{61}$

Hatîb el-Bağdâdî'nin fikhı hem rivayet (nakil) ve hem de rivayetin içeriği ile ilgilenmesi (anlamı/akıl) açısından değerce en yüksekteki ilim olarak gördüğü anlaşılmaktadır. Hatîb el-Bağdâdî, rivayetin anlaşılmasında rol aldığı ve pasif durmadığ için fikhı ve fakîhi öncelediğini söyleyebiliriz. Bu yaklaşım Gazzâlî’de de görülmektedir. Gazzâlî de

\footnotetext{
${ }^{58}$ Konu hakkında ilgili diğer rivayetler için bk. Hatîb el-Bağdâdî, Nasîhatu Ehli'l-Hadîs, thk. Abdülkerîm Ahmed el-Vüreykât, 1. Bask1, Mektebetü'l-Menâr, ez-Zerkâ h.1408, 31-35.

${ }^{59}$ Hatîb el-Bağdâdî, a.g.e., 37.

${ }^{60}$ Hatîb el-Bağdâdî, a.g.e., 40.

61 Hatîb el-Bağdâdî’nin aktardığı şu rivayette sadece karşıt grubun eleştirisinden kurtulma fikri yatmamaktadır. Aynı zamanda bir eksiğin giderilmesini isteme de bulunmaktadır: Hasan b. Muhammed b. Hasan el-Hallâl- Muhammed b. el-Abbâs el-Hazzâr-Ebû Bekir b. Ebî Davud-Ali b. Harşem dedi ki: "Çok defa Veki in şöyle dediğini duydum: "Ey gençler! Hadîsin fikhını öğreniniz. Ĕ̆er ki siz hadîsin fikhını (fikhü'l-hadîsi) iyi bilirseniz, ehli Rey size gâlib gelemez." Hatîb el-Bağdâdî, a.g.e., 41.
} 
aklın işlevsel olmasına göre ilimleri bir derecelemeye tabi tutmaktadır. ${ }^{62}$ Ona göre ilimler şu üç kısma ayrılır: Sırf aklî, sırf naklî hem aklî hem de naklî ilimler. Matematik, astronomi gibi ilimler sırf aklî ilimlerdir. Hadîs ve tefsir gibi sırf naklî ilimler ezbere dayalı, aklın pek işlevsel olmadığ herkesin elde edebileceği ilimlerdir. Hem aklî hem de naklî ilimlere ise fikıh ve fikıh usûlünü örnek olarak zikretmektedir. Ona göre ilimler tasnifinde en şerefli olan hem aklın hem de sem'in ortak kümesi olan bu ilimlerdir. Gâzzâlî fikıh ve fikıh usûlünün aklın ve şer'in özünden beslendiğini; onların ne şer'in kabul etmediği salt akla ne de aklın desteklemediği ve düzeltmediği salt taklide dayanmadığını belirtmektedir. ${ }^{63}$

\section{FAKÎHİN GÖREVLERI}

Hatîb el-Bağdâdî, Allâh'ın Peygamber'imize (s.a.v) gönderdiği İslâm'1 koruma görevini sahabe ve tabi'undan hüccet olanlara ve görüssleriyle şüpheleri kaldıranlara emanet ettiğini belirtir. Ona göre dinin korunması işi sahabe ve tabi'undan fakîh olanlara verilmiştir. ${ }^{64}$ Hatîb el-Bağdâdî dini korumayı fukahânın görevi kapsamında değerlendirir. Onun bu konudaki ifadesi şöyledir: "Onlar şeriatını korumayı ve dinde bilgi sahibi olmayı kendilerine görev olarak yüklediği fakihlerdir." ${ }^{65}$ Hatîb el-Bağdâdî, kendi görüşünü şu ayetlerle desteklemektedir: "Okumakta ve ögretmekte olduğunuz kitaba göre rabbanilerden olunuz." (Âli İmrân: 79); "Müminlerin hepsinin toptan sefere çıkmaları doğru değildir. Onların her kesiminde bir gurup dinde geniş bilgi elde etmek ve kavimleri (savaştan) döndüklerinde onları ikaz etmek için geride kalmalıdır"(etTevbe: 122).

Hatîb el-Bağdâdî bu ayetlerde Allah'ın müminleri iki gruba ayırdığını bir gruba cihadı vacip kıldığını; diğer gruba da dinde bilgi sahibi olmayı vacip kıldığını belirtir. ${ }^{66}$ Böylelikle müminler topyekûn cihada katılmayarak şeriat muhafaza edilmiş ve ülke sınırları korunmuş olur. Aksi halde ya şeriat bozulur ya da küffar ümmete galip gelir. ${ }^{67}$ Allah bu ayetler ile fakihlere dinde bilgi sahibi olmayı emrederek şeriatını muhafaza etmeyi amaçlamıştır. Allah cihada katılanlara da yeni çıkan olaylar ve nevazil hakkında "bilenlerden değilseniz, bilenlere sorun" (en-Nahl: 43) ayeti gereği fukahâya rücu etmeyi dinlerini onlardan sormayı emretmiştir. ${ }^{68}$

Hatîb el-Bağdâdî'nin bu ifadelerinde fukahâyı başvuru merci'i olarak gördügü aşikârdır. Bununla beraber fukahânın uğraş alanı hakkında da bilgi vermektedir: Nevâzil ve yeni gelişmelerin hükmünü araştırma. Fakîh bu meseleler hakkında incelemede bulunup bir cevaba ulaşarak diğer insanlara ulaştırır. Ona göre fakih bu şekilde dinin muhafazasına katkıda bulunmaktadır. Bu konular hakkında fukahâ uğraşıp incelemede bulunmaz ve problemlerin cevabı ile ilgilenmezse dinin gündelik hayata bakan tarafı olmayacak ve din, günün insanı için işlevini yitirmiş tarihsel bir olgu olacaktır. Bu meseleleri inceleyip bir sonuca ulaşma dinin işlevselliği anlamında güncelliğini sağlayarak muhafaza etmektir. Hatîb el-Bağdâdî bu anlamdaki muhafazayı fakihlerin görevi kapsamında değerlendirir.

\footnotetext{
${ }^{62}$ Hüccetü'l-İslâm Ebû Hâmid Muhammed b. Muhammed b. Muhammed b. Ahmed el Gazzâlî, elMüstasfâ, thk. Muhammed Abdüsselam Abdüşşafî, Dârü'l-Kütübi'l-İlmiyye, y.y 1993, 3.

${ }^{63}$ Gazzâlî, a.g.e., 3-4.

${ }^{64}$ Hatîb el-Bağdâdî, a.g.e., I, 69.

${ }^{65}$ Hatîb el-Bağdâdî, a.g.e., I, 69.

${ }^{66}$ Hatîb el-Bağdâdî, a.g.e., I, 69-70.

${ }^{67}$ Hatîb el-Bağdâdî, a.g.e., I, 70.

${ }^{68}$ Hatîb el-Bağdâdî, a.g.e., I, 70.
} 
Dinî koruma tek yönlü değildir. Fakîhlerin bulduğu cevaplar ancak toplum tarafindan karş1lık bulunca yani yaşanılınca anlam bulur. Bundan ötürü Allâh dinle uğraşmayıp savaşa giden gruba geri döndüklerinde dinleri hakkındaki bilgiyi fukahâya sormalarını emretmiş̧ir. Dinin bir kesim tarafından anlaşılması ve güncel problemlere cevap bulunması tek başına dinin muhafazasını sağlamaz. Bunca uğraşın ancak ulaşılan sonuçların fukahâ dışındaki kesimlerde ma'kes bulması ile anlam kazanır. Bundan ötürü Hatîb el-Bağdâdî'nin anlayışında dinin muhafazasının biri araştırıp öğrenme diğeri bunu ehline sorarak öğrenme şeklinde formüle edilerek sağlandığını ifade edebiliriz. Bu husus yukarıdaki ayette açık bir şekilde belirtilmektedir. Cihada katılanların geri döndüklerinde cevap bulabilmeleri için bir grubun geride kalıp din ilimleri ile uğraşmaları istenmektedir. Bilmeyenlerin de bilenlere sormaları ayrıca başka bir ayette emredilmiştir. Bu şekilde öğrenme ve sorma ile din işlevsel hale gelecek ve muhafaza edilecektir. Hatîb el-Bağdâdî, dinin muhafazası için cihad ve dinde bilgi sahibi olmayı birbirinden ayrı tutarak izah etmeye çalışmıştır. Onun bu konudaki ifadesi şöyledir: "Böylece (cihad eden ve geride kalıp din işiyle uğraşan iki grubun olması) mücahitlerle islam topră̆ korunmuş, müteallimlerle imanın şeriatı korunmuş olur."

Hatîb el-Bağdâdî'nin çağdaşı Cüveynî ise dini anlama ve savaş anlamındaki cihadı İslam'a davet başlığı altında ele almaktadır. Ona göre Allâh yolunda cihat etmek İslâm'a davetin ikinci boyutu olan güç kullanma kısmıdır. İslam'a davetin ilk boyutu İslam'ın delilleriyle tanıtılmasıdır. ${ }^{70}$ Cüveynî bu kısmın delil ve burhana dayanan tebliğ ve irşâd ile şüpheleri apaçık delillerle gidermek olduğunu belirtir. Ona göre hak açıkça anlatıldıktan delil ve burhanlar serdedildikten sonra dinden çıkan, haktan yüz çeviren ve inatçılar konumunda olan kâfirlerle Müslüman oluncaya ya da zimmet akdini kabul edinceye kadar savaşılır. ${ }^{71}$ Hatîb el-Bağdâdî cihadı ülke topraklarını koruma, din işiyle uğraşıyı da şeriatı koruma amacı olarak görmekte ve toprak ile dini korumayı bir birinden ayırmaktadır. Cüveynî ise cihadı sadece ülke topraklarını koruma aracı olarak değil aynı zamanda tebliğ ve irşadın ikinci sacayağı olarak görmektedir.

Hatîb el-Bağdâdî'ye göre Allah ulemâyı yeryüzündeki halifesi ve kulları üzerine kendi hücceti kllmış; peygamber ve uyarıcıdan sonra onlarla iktifa etmiş ve onların şehadetini kendi ve meleklerin şehadeti ile bir tutmuştur. ${ }^{72}$

Hatîb el-Bağdâdî'nin bu ifadesinde onun fukahâya bakış açısını ve onlara yüklediği görevleri şu şekilde sıralamak mümkündür.

1. Fukahâ yeryüzünde Allah'ın halifesidir.

2. Fukahâ insanların dini konularda dayanacakları hüccetir.

3. Fukahânın işlevi Peygamberlik kurumunun işlevinin devamıdır.

4. Onlar Allah katında değerlidir.

Hatîb el-Bağdâdî’nin fukahâyı yeryüzünün halifesi olarak görmesi Allah'ı tanıyıp bilmelerindendir Nitekim yukarıdaki cümleleri "Allah 'tan ancak alimler korkar" (Fâtır: 28) ayetini zikrettikten sonra sarf etmektedir.

\footnotetext{
${ }^{69}$ Hatîb el-Bağdâdî, a.g.e., I, 70.

${ }^{70}$ Cüveynî, Ğiyâsü'l-Ümem fi't-Tiyâsi'z-Zülem, thk. Abdü'l-Azim Mahmud ed-Dîb, Darü'l-Minhâc, Beyrut 2011, 344.

${ }^{71}$ Cüveynî, a.g.e., 344.

${ }^{72}$ Hatîb el-Bağdâdî, a.g.e., I, 70.
} 
Fukahânın diğer kullar üzerinde Allah'ın hüccet olduğunu şu ayetlere dayandırmaktadır: “...Peygamber'e veya ulu'l-emre götürselerdi, onlardan istinbat etmeye kadir olanlar onu bilirdi."(en-Nisâ: 83), “Allah'a resulüne ve ulu'l-emre itaat edin"(en-Nisâ: 59).

Hatîb el-Bağdâdî “ulu'l-emr" ile kast edilenin fukahâ olduğuna dair rivayetler aktarmaktadır. ${ }^{73} \mathrm{Bu}$ ayetlerin ilkinde bir mesele hakkında bilinmek istenen bilginin kaynağı olarak resul ve fukahâ gösterilmektedir. İstinbât kelimesinin ayette zikredilmiş olması meseleleri kavrama işinin Peygamber ve fukahâ tarafından bilinebileceğini göstermektedir. Dolayısıyla bu ayet fukahânın da bilgisini doğrulamakta ve onlara meşruiyet kazandırmaktadır. Hatîb el-Bağdâdî'nin bu ayeti zikrettikten sonra en-Nisâ 59. Ayeti zikretmesi bir nevi pekiştirme anlamı taşımaktadır. Ayette fukahâ Allâh ve Rasûlünden sonra üçüncü bir itaat merkezi olarak zikredilmektedir. "Allah, melekler ve ilim sahipleri, ondan başka ilâh olmadiğına adaletle şâhitlik ettiler."( Âli İmrân: 18) Ayeti ile onların tanıklıklarının Allâh ve meleklerle beraber zikredilmesi fukahânın konumunu göstermektedir.

Hatîb el-Bağdâdî, bu ayetleri istinbât yetisine sahip fukahânın bilgili olduklarının ayet tarafından tescil edildiğini; bundan ötürü de hem şahitlikleri Allâh ve meleklerin şahitliği gibi görüldüğünü hem de itaat edilmelerinin gerekli görüldüğünü ifade etmeye çalışmaktadır. Böylece fukahâ: a. Peygamberle beraber istinbât yetisine sahip; b. Allah ve Peygamberle beraber itaat edilmesi gereken; c. Allâh ve melekleri gibi şahitliği makbul bir kesim olarak sunulmaktadır.

Hatîb el-Bağdâdî ayetler ile fukahânın bilgisinin tescil edildiğini ortaya koyup Allah ve Peygamberle ilişkilendirip dinî konularda merci kaynağı olarak sunduktan sonra bilgi sahibi olmayanların tavırlarına geçer. O, "Bilenler ile bilmeyenler bir olur mu" (ezZümer: 9) ayetini zikrederek ${ }^{74}$ ilim sahibi olmayanların yukarıda zikredilen kısımda olmadıkları ve dolayısıyla onların bilgisinin alimlerin bilgisi gibi olmadığını belirtmek ister. Böylelikle ilim sahibi olmayanlar bilenlere sormalı ve bilenlerin kendilerine verdiği bilgiye göre davranmalıdır. Fukahânın bilgisinin meşruiyeti temellendirildikten ve insanlar için anlamı tespit edildikten sonra onlara din konularında danışma emredilerek dinin muhafazası yukarıda ifade ettiğimiz gibi sağlanmaktadır.

Hatîb el-Bağdâdî’nin "Peygamber ve uyarıcıdan sonra onlarla iktifa etmiş" şeklindeki ifadesi alimlerin ifa etikleri görevin nebevi işlevin devamı olarak gördüğünü göstermektedir. Allâh'ın, Peygamber ve uyarıcı yerine alimlerle yetinmesi ifa edilen görevin keyfiyeti itibariyle benzer olduğuna işaret eder. $\mathrm{O}$ eserinde alimlerin Peygamberlerin varisi olduğu şeklindeki hadîsi de zikreder. ${ }^{75} \mathrm{Bu}$ şekildeki bir ilişkilendirme ile fukahâya dinî referans olması açısından meşruiyet kazandırılmış olmakta, halk nezdindeki itibarları sağlanmaktadır. Ancak Peygamberle ilişkilendirmenin ve Peygamber görevinin devamının sınırı tartışılmıştır. Peygamberlerin vahiy alma, tebyin ve tebliğ görevleri olduğu; alimlerin vahiy alma dışındaki görevleri yerine getirmede onun varisi olduğu şeklindeki kabul sünnî anlayışı yansıtır. Örneğin Cüveynî alimleri nebiler yerine şeriatı uygulayanlar olarak tavsif etmektedir. ${ }^{76}$ Uygulayıcı olmak zaten daha önce tespit edilmiş kuralların hayata geçirilmesi demektir. Şeriatın uygulanması ve uygulanabilir kılınması biri tebliğ diğeri tebyin olmak üzere iki görevi gerekli kılmaktadır. Özellikle uygulanabilir kılma ictihâd

\footnotetext{
${ }^{73}$ Hatîb el-Bağdâdî, a.g.e., I, 126-131.

${ }^{74}$ Hatîb el-Bağdâdî, a.g.e., I, 70.

${ }^{75}$ Hatîb el-Bağdâdî, a.g.e., I, 105.

${ }^{76}$ Cüveynî, a.g.e., 462.
} 
mekanizmasının işletilmesini zorunlu kılar. Bu da fukahânın faaliyet alanı kapsamına girmektedir. Hatîb el-Bağdâdî'nin eserinde yer verdiği ve bizim de yukarıda aktardığımız bir hadîste geçen "Muallim olarak gönderildim" ifadesi ile fukahânın ifa ettiği görevin Peygamber'in ifa ettiği işlerden olduğu açık bir şekilde belirtilmektedir. ${ }^{77}$

Hatîb el-Bağdâdî aktardığı bir rivayette Peygamberler ile fukâhanın hüküm vermedeki benzerliğine değinmektedir. Söz konusu bu rivayette enbiyanın meclisi ile fukahânın meclisi arasında insanlar hakkında hüküm vermeleri üzerinden benzerlik kurulmaktadır. Fukahâ'nın Peygamber'in varisi olması bu benzerlik üzerinden somutlaştırılmaktadır. ${ }^{78}$ Bir önceki başlıkta Allâh'ın Peygamber'e gönderdiği ilim ve hidayetin taşıyıcısı olarak insanların kategorize edilmesi ve Peygamberi en iyi temsil eden grup olarak fukahânın tasvir edilmesinde de fukahânın Peygamberle ilişkisi başka bir açıdan izah edilmeye çalışılmaktaydı.

Fukahânın genel olarak da ulemanın ifa ettiği görevin Peygamber'in görevine benzetilerek onunla ilişkilendirilmesi Hatîb el-Bağdâdî'ye has bir durum değildir. Onun çağdaşı Cüveynî de ulema ile Peygamber arasında nesih teorisi üzerinden benzerlik kurar. Peygamberlerin zamanında, ahkâmın nesih ile değişmesi imkânı bulunmaktaydı. Nesihle değişen ahkâm, ümmet hakkında Allah'ın hükmünün değişmesi anlamına gelmekteydi. Aynı şekilde âlimlerin ictihâdlarının değişmesi de fetva isteyenler hakkında Allah'ın hükmünün değişmesi itibariyle nesihle değişen Allah emirlerine benzemektedir. ${ }^{79}$ Esasında hem Hatîb el-Bağdâdî hem de Cüveynî ilişkiyi ifa edilen görev yani muhatap kitle üzerindeki rolleri üzerinden kurmaktadırlar. Her ikisi de fukahâyı dini anlamda insanlar üzerinde hüküm verme yetkisi ve görevi ile Peygamber'e benzetmektedirler.

Fakihlerin ictihâdlarının inananlar açısından anlamı ismet sıfatını taşımamalarına rağmen Peygamberle ilişkilendirilerek sağlanmaya çalışılmıştır. Fukahânın Peygamber'in varisleri olmalarının ile Peygamber'e gönderilen ilim ve hidayeti en iyi kavrayan ve aktaran kesim olanların fakihler olduğunun belirtilmesi kurulmaya çalışılan bu ilişkinin dayanaklarını teşkil etmektedir. Bununla beraber yukarıda Hatîb elBağdâdî'nin de aktardığı ayetler ve onların anlaşılmasına dair aktardığı rivayetler fukahânın dini anlamada merci kaynağı olduğunu gösteren diğer delillerdir.

\section{SONUÇ}

Hicri beşinci asırda yaşamış olan Hatîb el-Bağdâdî, İslâmî ilimlerin birçok alanında çalışmaları olmakla birlikte en çok hadîs alanında şöhret bulmuştur. O kendi çağındaki muhaddîslerin sadece rivâyete dayanan ilim anlayışını doğru bulmayarak fikıhla ilgilenmelerini tavsiye etmiştir. Fikıh ona göre gerek rivayeti gerekse de dirayeti (anlama) barındırması açısından bir ilim talebesinin müstağni kalamayacağı bir ilimdir. Fakih yerine getirdiği bu görev sayesinde Peygamber'in hakiki varisi olmaktadır. Söz konusu bu veraset Peygamber' in Allah'tan aldığı ilim ve hidayeti temsil etmedir. Hatîb el-Bağdâdî'ye göre fukahâ ayetlerde Peygamber ile beraber istinbât yetisine sahip ve kendilerine dini konularda rücu edilip itaat edilmesi gereken ve dini muhafaza işinin

\footnotetext{
${ }^{77}$ Hatîb el-Bağdâdî, a.g.e., I, 88-90.

${ }^{78}$ Sehl b. Abdullah et-Tüsterî şöyle der: "Kim enbiyanın meclislerine bakmak isterse alimlerin meclisine baksın. Bir adam şöyle sorarak gelir: 'Ya falan! eşi üzerine şöyle şöyle yemin eden adam hakkında ne dersin'. (alim de) 'eşi boştur der'. Başka bir adam gelir ve 'eşi üzerine şöyle şöyle yemin eden hakkında ne dersin'. (alim de) derki: 'bu sözüyle yemini geçersizidir'. Bu ancak nebi ve alimin yetkisindedir'. Hatîb el-Bağdâdî, a.g.e., I, 149.

${ }^{79}$ Cüveynî, a.g.e., 463.
} 
kendilerine yüklendiği kimselerdir. Fukahâ dini anlayarak yeni gelişen olayların hükmünü ictihâdı ile tespit ederek onun dinamizmini sağlar. Böylelikle din tarihsel bir olguya dönüşmekten kurtularak yaşanabilir hale gelince korunmuş olmaktadır. Söz konusu bu koruma, biri anlama (beyân), diğeri anlatma (tebliğ) olan Peygamberliğin iki fonksiyonunu barındırmaktadır. Dolayısıyla bu iki fonksiyonu Peygamberden sonra hakiki anlamda fukahâ tarafından yerine getirildiği için onun gerçek varisleri fukahâ olmaktadır.

\section{KAYNAKÇA}

ARPAGUŞ, Hatice K, "Bir Telif Türü Olarak İlmihal Tarihi Geçmişi ve Fonksiyonu", Marmara Üniversitesi İlahiyat Fakültesi Dergisi, S. 22, s. 25-56.

CÜVEYNÎ, İmâmü'l-Haremeyn Ebü'l-Meâlî Rüknüddîn Abdülmelik b. Abdillâh b. Yûsuf et-Tâî en-Nîsâbûrî, el-Varakât, thk. Muhammed Hasan Muhammed Hasan İsmail, Dârü'l-Kütübi'l-İlmiyye, Lübnan 2010. el-Burhân, thk. Abdülazîm ed-Dîb, 1. Bask1, Katar h.1399.

Ğiyâsü'l-Ümem fi't-Tiyâsi'z-Zülem, thk. Abdü'l-Azim Mahmud ed-Dîb, Darü'l-Minhâc, Beyrut 2011.

EŞIT, Davut. Hicrî IV-V. Asırlarda Irak-Horasan'da Şâfi 'î Fıkıh Usûlünün Gelişimi, Ankara Üniversitesi Sosyal Bilimler Enstitüsü, Yayınlanmamış Doktora Tezi, Ankara 2017.

"Klasik Dönem F1kıh Usûlü Eserlerinde Bilginin Kısımları”, e-Şarkiyat İlmi Araştırmaları Dergisi, cilt: 10, sayı: 1, 2018.

EŞIT, Davut, Muhammet Enes Kala, “Onüçüncü Yüzyıl İslâm Hukuk Felsefesinde Bilginin Mahiyeti -Âmidî ve Zerkeşî Örneği-" Uluslararası 13. Yüzyılda Felsefe Sempozyити Bildirileri, Y1ldırım Beyazıt Üniversitesi, Ankara 2014.

GAZZÂLÎ, Hüccetü'l-İslâm Ebû Hâmid Muhammed b. Muhammed b. Muhammed b. Ahmed, el-Mustasfâ, thk. Muhammed Abdüsselam Abdüşşafî, Dârü'l-Kütübi'l-İlmiyye, y.y 1993.

HATÎB EL-BAĞDÂDÎ, Ebû Bekr Ahmed b. Alî b. Sâbit b. Ahmed b. Mehdî elBağdâdî, Tarîhu Bă̆dâd, thk. Beşâr 'Avâd Ma'rûf, Dârü'l-Ğarbi'l-İslâmî, Beyrut 2002.

el-Fakîh ve'l-Mütefakkîh, thk. Ebû Abdirrahman Adil b. Yusuf. 1. Bask1, Dârü İbni'l-Cevzî, Suud 1996.

.............., Nasîhatu Ehli'l-Hadîs, thk. Abdülkerîm Ahmed el-Vüreykât, 1. Bask1, Mektebetü'l-Menâr, ez-Zerkâ h.1408.

İBN FÛREK, Ebû Bekr Muhammed b. el-Hasen el-İsfahânî en-Nîsâbûrî, Kitâbü'lHudûd fi'l-Usûl, 1. Bask1, Dârü'l-Ğarbi'l-İslâmî, Beyrut 1999.

İBN KESÎR, Ebü'l-Fidâ' İsmâîl b. Ömer b. Kesîr b. el-Kureşî el-Basrî ed-Dımaşkî eşŞâfiî, el-Bidâye ve'n-Nihâye, thk. Ali Şirî, 1. Bask1, Dâru İhyâyi't-Türâsi'l-Arabî, y.y $1412 / 1998$.

İBNÜ'L-CEVZÎ, Ebû'l-Ferec Cemâluddin Abdurrahman b. Ali, el-Muntazam fi Tarîhi'l-Mülûk ve'l-Ümem, thk. Muhammed Abdülkadir 'Atâ-Mustafâ Abdulkadir 'Atâ, 1. Bask1, Dârü'l-Kütübi'l-İlmiyye, Beyrut 1412/1992.

İSTEMİ, Fuat. Hicret Bağlamında Tarih ve Hadis Metodolojileri, Ankara Okulu Yayınları, Ankara 2017. 
KANDEMIR, Mehmet Yaşar "Hatîb el-Bağdâdî", Türkiye Diyanet Vakfi İslam Ansiklopedisi, İstanbul 1997, XVI, ss. 452-460

ÖMERÎ, Ekrem Ziyâ, Mevâridu'l-Hatîbi'l-Băgdâdî fi Târihi Băgdâd, Dâru Tîbe, Riyad 1985.

SARI, Necmi, el-Hatîb el-Băgdâdî ve Hadîs Illmindeki Yeri, 1. Bask1, Ümmülkura Yayınevi, İstanbul 2003.

SEM`ÂNî, Abdülkerim b. Muhammed b. Mansûr et-Temimî, el-Ensâb, thk. Abdurrahman b. Yahya el-Mua'llimî ve diğerleri, 1. Bask1, Meclisu Dâiretü'1Me‘arifi'l-Osmaniyye, Haydarâbâd 1412/1962.

ŞİRÂZÎ, Ebû İshâk Cemâlüddîn İbrâhîm b. Alî b. Yûsuf, el-Lüma 'fi Usûli’l-Fıkh, thk. Abdülkâdir el-Hatîb el-Hasanî, 1. Baskı, Dârü'l-Hadîs el-Kâtaniye, Beyrut 2013.

TAHHÂN, Mahmud, el-Hâfiz el-Hatîb el-Băgdâdî ve Eseruhu fi 'Ulûmi'l-Hadîs, Dâru'l-Kur'an'i'l-Kerîm, Beyrut 1981.

TAKIYÜDDIN ES-SÜBKÎ, Tâcüddîn Abdülvehhâb, Tabkâtü'ş-Şâfi 'iyyetü'l-Kübrâ, thk. Mahmud muhammed et-Tanâhî, Abdü'l-Fettâh. 2. bask1, y.y h.1413.

UBEYDÎ,, Abbâs Ali Hamid, el-Menhecü'l-Usûlî li'l-Hatîb el-Bağdâdî fi Kitâbihi elFakîh ve'l-Mütefakkîh, Merkezü'l-Buhûs ve'd-Dirasât el-İslâmiyye, Irak 2012.

ZEHEBÎ, Ebû Abdillâh Şemsüddîn Muhammed b. Ahmed b. Osmân et-Türkmânî elFârikî ed-Dımaşkî, Tezkîretü'l-Hüffâz, Dârü'l-Kütübi'l-İlmiyye, Beyrut 1419/1998.

.Târîhu'l-İslâm ve Vefeyâtü'l-Meşâhir ve'l'Alâm, thk. Beşşâr 'Avvâd Ma'rûf, Dârü'l-Ğarbi'l-İslâmî, Beyrut 2003.

Siyeru A 'lâm 'in-Nübelâ, Dârü'l-Hadîs, Kahire 1427/2006.

ZİRİKLÎ, Ebû Gays Muhammed Hayrüddîn b. Mahmûd b. Muhammed b. Alî b. Fâris ed-Dımaşkî, el-A 'lâm, 15. Bask1, Dârü’l-İlim li'l-Melâyîn, Beyrut 2002. 